\title{
HOXD11 Gene
}

National Cancer Institute

\section{Source}

National Cancer Institute. HOXD11 Gene. NCI Thesaurus. Code C97580.

This gene is involved in limb morphogenesis. 